International Journal of Publication and Social Studies

$\operatorname{ISSN}(e): 2520-4491$

$\operatorname{ISSN}(p): 2520-4483$

DOI: 10.18488/journal.135.2020.52.115.130

Vol. 5, No. 2, 115-130.

(C) 2020 AESS Publications. All Rights Reserved.

URL: www.aessweb.com

check for
updates

\title{
MODEL OF HALAL TOURISM MANAGEMENT IN BUKITTINGGI CITY, WEST SUMATRA PROVINCE, INDONESIA
}

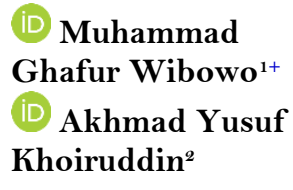

\author{
${ }^{t}$ Departement of Islamic Economics, State Islamic University of Sunan \\ Kalijaga, Indonesia. \\ Email:muhammad.wibowo@uin-suka.ac.id Tel:+628156886013 \\ ${ }^{2}$ Departement of Islamic Banking, State Islamic University of Sunan \\ Kalijaga, Indonesia. \\ Email:akhmad.khoiruddin@uin-suka.ac.id Tel:+6285747843698
}

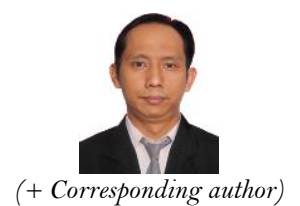

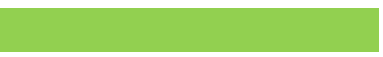

Article History

Received: 3 July 2020

Revised: 7 August 2020

Accepted: 9 September 2020

Published: 24 September 2020

\section{Keywords}

Halal tourism

Penta helix

Collaboration

AHP

SWOT

\section{ABSTRACT}

The development of the halal tourism industry in Indonesia has increased in recent years. It is along with the support of the central government and also some local governments. Bukittinggi City in the Province of West Sumatra is a tourist city that has the potential to develop halal tourism. This study examines the model of managing Halal Tourism in the Bukittinggi City, West Sumatra Province, with the Penta Helix model that must involve various parties. The data was obtained from a questionnaire filled out by tourism policy stakeholders in the Bukittinggi City, which included business operators, local government officials, academics, religious leaders, and community leaders. The data is then processed by calculating the Priority matrix to produce alternative policies for the development of halal tourism. Collaboration between all components is very crucial. Policy priorities that must be selected and implemented by the Bukittinggi City government and all tourism people to develop halal tourism based on Analytical Hierarchy Process (AHP) and SWOT analysis are a collaboration with all tourism stakeholders, increase awareness of the importance of halal products, including in the field of tourism, and overcoming the limitations of halal restaurants and sharia hotels certified by Indonesian Ulama Council (MUI). This research contributes to the development of halal tourism in other areas to remain in accordance with Islamic values but also in harmony with local customs and culture.

Contribution/ Originality: This study contributes to the development of a halal tourism management model at the city level by considering local wisdoms.

\section{INTRODUCTION}

The large population of Muslims in the world, which reaches around 1.5 billion people or $22 \%$ of the total population, makes various aspects of tourism for Muslims essential to be observed. It is proven by the seriousness of the Organization of Islamic Cooperation (OIC) reviewing and publishing a book entitled "Strategic Roadmap for the Development of Islamic Tourism in OIC Member Countries" in 2017. With the number of 57 member countries, the OIC seeks the potential for Muslim tourism (outside the Hajj and umrah) reached 80 billion US $\$$ in 2006, which then increased to 145 US $\$$ in 2014 (OKI-SESRIC, 2017).

Various countries in Southeast Asia, such as Malaysia, Thailand, and Singapore, have been developing halal tourism for several years. Some countries in the Middle East also have high halal tourism potencies such as Saudi Arabia, Iran, United Arab Emirates, and Turkey (Yan, Zahari, Ismail, \& Zain, 2017). Some countries with a 
majority of non-Muslim residents have also provided halal tour packages, such as Japan and New Zealand. It is in line with the study of Mansouri (2014) regarding efforts to supply the needs for halal tourism in Thailand. Thus, this significant development is one of the reasons for the emergence of the World Halal Tourism Award, which is in 2016, Indonesia received 12 awards (Agustin, 2019). From the 12 winning categories, West Sumatra Province was able to win three categories: Halal Tour Operators, Halal Destinations, and Halal Culinary Destinations.

According to Statistics Indonesia (BPS) data presented in Table-1, the number of foreign tourists visiting West Sumatra amounted to 54,369 people. The majority of them visited Bukittinggi, a total of 31,841 tourists. The number of foreign tourists to Bukittinggi has fluctuated in recent years, 2017: 30,412 visitors; 2016: 27,516 visitors; 2015: 25,970 visitors; 2014: 32,501 visitors. When broken down by country of origin, tourists from Malaysia are the most visiting Bukittinggi in 2018 (Tarigan \& Alfindo, 2019).

Table-1. Data of foreign tourists visiting Bukittinggi by Nationality in 2018.

\begin{tabular}{|c|c|c|c|c|c|c|c|c|}
\hline No & Country & Amount & No & Country & Amount & No & Country & Amount \\
\hline 1 & Malaysia & 21.102 & 10 & Australia & 408 & 19 & Rusia & 98 \\
\hline 2 & Belanda & 3.449 & 11 & Amerika & 397 & 20 & New Zealand & 97 \\
\hline 3 & Jerman & 1.008 & 12 & Singapura & 357 & 21 & Spanyol & 97 \\
\hline 4 & Jepang & 793 & 13 & Taiwan & 239 & 22 & Irlandia & 96 \\
\hline 5 & Korea & 641 & 14 & Italia & 216 & 23 & Swedia & 93 \\
\hline 6 & Perancis & 543 & 15 & Austria & 159 & 24 & Polandia & 79 \\
\hline 7 & China & 543 & 16 & Swiss & 125 & 25 & Filipina & 71 \\
\hline 8 & Inggris & 516 & 17 & Thailand & 107 & 26 & Lain-lain & 98 \\
\hline 9 & Kanada & 411 & 18 & Belgia & 98 & & & \\
\hline
\end{tabular}

However, until now, there is no formal concept or model of halal tourism that is agreed upon by all tourism stakeholders in West Sumatra, including Bukittinggi City as a tourist city. Local regulations regarding halal tourism are still being discussed by the Local House of Representative (DPRD) of West Sumatra Province and are targeted to be completed by the end of 2019 (Masyrifina, 2019) although it eventually retreated to 2020 (Elfisha, 2019). On the other hand, West Sumatra entered into one of 10 halal tourism locations developed by the central government. The other nine sites are Aceh, Riau, and the Riau Islands, Jakarta, West Java, Central Java, Yogyakarta, East Java, NTB, and South Sulawesi (Zuhriyah, 2019). Tourism potencies (both general and halal) in West Sumatra Province are tremendous, especially Bukittinggi City, which is an icon of tourism in West Sumatra. A general guideline that can be used is the Fatwa of National Sharia Council (DSN) Number 108/DSNMUI/X/2016 concerning Guidelines for Organizing Tourism Based on Sharia Principles.

The development of tourism is impossible without the role of the government, especially the local government. Various studies show that local governments, as regulators and policy executors, have a very crucial role in tourism development and management. The government needs to coordinate various parties involved in the tourism industry to improve the quality of the destination, accessibility, to the comfort of tourists (Simamora \& Sinaga, 2016). In addition, The authority of local government in Bukittinggi, along with related stakeholders, is responsible to develop the potential halal tourism in Bukittinggi, West Sumatra province. Some research in multiple areas shows the vital role of the government in the field of tourism.

For example, the development of Rammang-Rammang stone forest tourism objects in Maros Regency, South Sulawesi, shows the successful collaboration between local, provincial, and district governments (Harnida \& Tahir, 2012). Experience in Cyprus shows that how to develop a tourism policy is very important, especially the involvement of stakeholders (Ismet \& Abuhjeeleh, 2016). Governments in the Central American region are also very instrumental in the field of tourism through various policies that encourage increased competitiveness, freedom, and economic development (Kubickova, 2016). The local government is also very instrumental in raising awareness and support of citizens to preserve the historical tourism city in Portugal (Vieira, Rodrigues, Fernandes, 
\& Pires, 2016). The Gilan city government in Iran is also developing halal tourism. They optimize the potency of tourist attractions and natural wealth within the framework of halal tourism (Kamal \& Shabgoo, 2017).

In a nutshell, Bukittinggi has an enermous potential of halal tourism, however, it has not been managed optimally. The regional government does not yet have a comprehensive concept of halal tourism management involving all relevant parties and stakeholders. Therefore, this study aims to produce a halal tourism management model that includes all components of the community. Besides, this study also formulated policy priorities for the management of halal tourism in Bukittinggi city. This study uses primary data from stakeholders using a questionnaire instrument. The data is then processed quantitatively to produce a policy priority. Furthermore, qualitatively, this research will arrange a tourism management model based on the Penta Helix model. It is essential to do so that the emergence of the concept of halal tourism does not harm anyone. Also, Bukittinggi City, as a tourism city icon, can compete with halal tourism icons in other regions and countries.

\section{REVIEW OF LITERATURE}

\subsection{Halal Tourism and Local Wisdom of Bukittinggi}

The term halal is defined as "permitted, in connection with no restrictions, and enforcing the law of God, and permissible," therefore, the word halal refers to everything that is permitted in speech or behavior that is not contrary to sharia (Masful, 2017). Furthermore, the word tourism is not explicitly mentioned in the Qur'an and the hadith. However, tourism is often equated with the term rihlah (journey) as contained in al-Qur'an surah alQuraysh. The concept of travel can also be found in the al-Qur'an 29:20, which encourages people to travel on earth to take lessons from God's creation and take His grace. Rihlah in question can be a trip to Mecca and Medina (a series of pilgrimage), or a trip to another place for various purposes, including for pleasure (Suradin, 2018).

The Organization of Islamic Cooperation (OIC) defines Islamic tourism as a tourism product and process that is following the values or principles of Islamic teachings (OKI-SESRIC, 2017). Other terms that are also commonly used are halal tourism, sharia tourism, and Muslim-friendly tourism. Islamic tourism is closely related to the satisfaction of tourists in enjoying attractions that do not violate the prohibitions of Islamic teachings in various aspects. Some elements which are forbidden to be consumed by Muslims must be kept entirely away from objects or tourist events. For example, prohibited alcoholic drinks, gambling, prostitution, and so forth.

Halal tourism is an activity that is related to various facilities and services provided by the community, business people, government, and regional governments that meet Islamic regulations (Teguh, 2017). Tourism development should consider the principles such as diversity, uniqueness, cultural and natural characteristics, and human travel needs. It consists of the tourism industry, tourist destinations, marketing, and tourism institutions (Government Law No. 10/2009 on Tourism). Therefore, halal tourism is not only limited to religious matters.

In line with the development of Halal tourism in Bukittinggi, The Minangkabau tribe, which is a native population and the majority in West Sumatra, firmly holds the basis of religion and tradition. The life philosophy of the Minangkabau people is Adat Basandi Syara', Syara' Basandi Kitabullah (adat based on Shari'a and Shari'a-based on the Book of Allah SWT, i.e., Al-Qur'an and Prophetic traditions) or often abbreviated as ABS-SBK (Putiah, 2007). This philosophy has the meaning that the Minangkabau custom is based on syara' or religion (in this case, Islam). The sharia is based on the holy book that came from Allah, namely the al-Qur'an. The Syariah is Islamic law, so it is not Minangkabau people if it does not adhere to the Islamic faith (Agus, Syahrizal, \& Meiyenti, 2006; Putiah, 2007). Therefore, the Minangkabau people in West Sumatra are people who, in their daily lives, are firmly adhering to their customs and culture. The Government of West Sumatra Province explicitly includes the ABS-SBK as the development foundation in the Long and Medium Term Development Plan (RPJPM) document. In fact, in West Sumatra, there is no village government known, but there is a Nagari, which is an element of government as well as adat under the sub-district. Various local regulations (Perda) have been prepared to implement ABS-SBK in people's lives, such as the Local Anti-Disease Regulation and the Muslim Fashion Regulation (Agus et al., 2006). 


\subsection{Halal Tourism Model and Development.}

The study of the potential of halal tourism received attention several years ago. Bhuiyan, Siwar, Ismail, and Islam (2011) use the term Islamic Tourism when analyzing the potential for Islamic tourism in several areas of the east coast of Malaysia. Bhuiyan found that some of these regions had various aspects that were in line with Islamic values, principles, and history. The existing Islamic cultural heritage is very likely to be developed into a center for Islamic tourism in Malaysia.

Research conducted by Yan et al. tries to describe the development and potential of halal tourism in various countries (Yan et al., 2017). For the Southeast Asian region, countries with high potential of halal tourism include Malaysia, Indonesia, Thailand, and Singapore. Meanwhile, in the Middle East also have high halal tourism potencies such as Saudi Arabia, Iran, United Arab Emirates, and Turkey. Some countries with a majority of nonMuslim residents have also provided halal tour packages, such as Japan and New Zealand. It is in line with studies from Mansouri (2014) about efforts to ensure the need for halal tourism in Thailand.

Still, in the context of Indonesia, Jaelani (2017) try more deeply to analyze the potential and prospects for halal tourism in the country. The tourism industry aims not only to provide material and psychological aspects for tourists themselves but also to contribute to increase government revenue. This halal tour is not exclusive, but it is inclusive for all tourists. The essence of halal tourism emphasizes the principles of sharia in the management of tourism and services that are polite and friendly to all tourists and the surrounding environment.

Previous studies emphasize the critical role of government in the management of regional tourism. However, they have not explicitly and clearly stated which stakeholders should be involved. Other than that, what kind of roles do each party need to play? This research intends to formulate a halal tourism management model that includes all components of the community. This study also wants to arrange a priority order of policies that support the development of halal tourism, especially in the city of Bukittinggi.

\subsection{Penta Helix Model}

The Penta Helix model is a collaborative management model of an activity that involves five interested parties. In the context of tourism management, the Ministry of Tourism introduces the Penta Helix Model by pouring it into Ministerial Regulation (Permen) Tourism Number 14 of 2016 concerning Guidelines for Sustainable Tourist Destinations. The regulation emphasizes that to create collaboration and ensure the quality of activities, facilities, services, and to create experiences and value of tourism benefits to provide advantages and benefits to the community and the environment, it is necessary to have a tourism model through optimizing the roles of Academic, Business, Community, Government, and Media or commonly abbreviated as ABCGM (Teguh, 2017).

Empirically, the Penta Helix model has been applied in developing collaborative tourism management models in various regions, such as in East Java (Aribowo, Wirapraja, \& Putra, 2018); Semarang city (Yuniningsih, Darmi, \& Sulandari, 2019); Parepare city and Bone region (Junaid, 2019). The Penta Helix model can also be applied in various fields and issues of society, such as developing excellent products (Muhyi, Chan, Sukoco, \& Herawaty, 2017), village potential development (Yunas, 2019) and regional marketing communication (Wulandari, Chotijah, \& Suadnya, 2019). In the context of the development of halal tourism in Bukittinggi City with the Penta Helix model, the researchers conducted interviews with tourism stakeholders. Furthermore, the parties identified should be involved in collaborative tourism management in the role of the Penta Helix (Academic, Business, Community, Government, and Media/ABCGM).

\subsection{The A'WOT Method}

This research is field research that digs data from the community that is analyzed quantitatively. This research takes place in West Sumatra Province, specifically Bukittinggi City, which describes itself as a Tourist City and also 
applies the Analytical Hierarchy Process (AHP) method and analysis of strengths, weaknesses, opportunities, and threats (SWOT) or commonly called A'WOT.

Analytical Hierarchy Process (AHP) is a model that provides an opportunity for individuals or groups to develop ideas and define problems by making their assumptions and obtaining the desired solutions from them. According to Hung, Lin, and Hsueh (2018) the analytic hierarchy process is a method or tool that can be used by a decision-maker to understand the condition of a system, help predict and make decisions. AHP is a method that models priority problems that are not structured, such as in the economic, social, and management sciences. The advantages of this method are simple and not many assumptions. This method is suitable for solving strategic and macro problems.

The first stage of A'WOT is identifying internal factors (weaknesses and strengths) and external factors (opportunities and threats). The second step is compiling the Internal Strategic Factors Analysis Summary (IFAS) matrix and the External Strategic Factors Analysis Summary (EFAS). The third stage is analyzing the space matrix intending to find out halal tourism in Bukittinggi City is in the awareness I, II, III, or IV. The last step is to compile a SWOT matrix, which describes opportunities and threats that can be adjusted to the strengths and weaknesses that are owned (Fabac \& Zver, 2011).

SWOT analysis is based on the logic of thinking in determining policy strategies where an organization must maximize its strengths and opportunities and minimize the factors of weakness and threat to achieve a balance between internal and external factors (Kamal \& Shabgoo, 2017). According to Ruano (2018) AHP is an appropriate analysis for decision-makers to determine qualitative and quantitative decisions based on their aspects. AHP can also provide a clear and rational picture of the decisions made. AHP is intended to create an unstructured problem model, generally used to solve measurable problems, problems that require decisions or complex or unpredictable situations, in cases where there is limited data and are only qualitative based on opinion, experience, and intuition. This method can be applied in the development of tourism planning in the city (Jeon \& Kim, 2011; Oreski, 2012) or country level (Ozdemir \& Demirel, 2018; Wickramasinghe \& Takano, 2010).

\section{RESEARCH METHOD}

3.1. Research Design

This research is a quantitative study using primary and secondary data. Primary data obtained by observing, questionnaires, and interviews directly with respondents. Secondary data in the form of documentation and data on tourism and other aspects in Bukittinggi City. Secondary data comes from the annual report of the Bukittinggi City and West Sumatra Province Tourism Office in 2018-2019. Data also comes from Statistics Indonesia "Bukittinggi in Figures 2019". Respondents in this study were grouped into two types, expert respondents and tourists. Sampling-based on specific objectives (purposive sampling) for the expert respondents. The criteria in the purposive sampling method are: 1) respondents are practitioners, regulators, and community leaders related to tourism activities, 2) respondents have the authority to influence tourism policy in the City of Bukittinggi.

\subsection{Respondents}

The respondents from the expert were: (1) Bukittinggi City Tourism Agency, (2) Indonesian Ulama Council (MUI), (3) Bukittinggi City Research and Development Agency (Bapelitbang), (4) Association of the Indonesian Tours \& Travel Agencies (ASITA), (5) Indonesian Restaurant and Hotel Association (PHRI), (6) Academician from IAIN Bukittinggi, (7) Academician from Padang State University, (8) Lembaga Kerapatan Adat Minangkabau (LKAAM), (9) Bukittinggi City Local House of Representative (DPRD), (10) tourist destinations management. The tourists were selected as many as 60 respondents to know their response to the implementation of halal tourism in Bukittinggi. 


\subsection{Instruments}

The research instrument was in the form of a questionnaire consisting of two types, 1) a questionnaire for experts, 2) a questionnaire for tourists. Researchers observed tourism activities in the city of Bukittinggi by visiting several tourist destinations and then recorded various attractions, facilities, services, and public interactions at these locations. The interviews were conducted with experts who were respondents in filling AHP questionnaire. The experts were questioned about the potential, opportunities, and plans for developing halal tourism in Bukittinggi City.

To compile a questionnaire for experts, a focus group discussion was first conducted to produce a SWOT analysis (Strengths, Weaknesses, Opportunities, and Threats). The discussion involved several academicians, government officials, and tourism practitioners. From the description of the SWOT analysis, the policy priority choices that need to be taken by halal tourism stakeholders in the City of Bukittinggi are made using the AHP (Analytical Hierarchy Process) method. The questionnaire for tourists contains various questions about their response to the suitability of tourism practices in Bukittinggi with the values of Islamic teachings.

\subsection{Data Collection Procedure}

Secondary data were obtained from the BPS report and the Bukittinggi City Tourism Office. As for the primary data were obtained from expert respondents and tourists. The data collection step is carried out through several stages. First, giving AHP questionnaires developed from SWOT analysis to experts, as well as conducting interviews after they filled out the questionnaire. Second, offering questionnaires on the response of tourists in the main destinations of Bukittinggi City (Jam Gadang and Sianok Canyon), as well as making observations on the state of these attractions. Third, analyzing the content of secondary data, interviews, tourist questionnaires, and observations to produce a Penta Helix model of the management of halal tourism in the City of Bukittinggi. Fifth, tabulating and processing data on AHP questionnaires from experts to create priority policies for the management of halal tourism in Bukittinggi City.

\subsection{Data Analysis Procedure}

To build the Penta Helix halal tourism management model in Bukittinggi City, the researchers elaborated on various data obtained, both primary and secondary. Primary data derived from the observation of tourist destinations and interviews of the expert respondents. As for secondary data from various government reports used to support the analysis. The questionnaire for tourists was analyzed descriptively to illustrate their response to tourism practices in Bukittinggi City.

The questionnaire for experts was analyzed quantitatively, with each respondent providing an assessment of how important a policy is compared to other policies. The application of the A'WOT method is carried out according to the following stages (Kangas, Pesonen, Kurttila, \& Kajanus, 2001; Taherdoost, 2017):

1. Perform a SWOT analysis. Relevant internal and external environmental factors are identified for inclusion in the analysis.

2. Draw the image of the hierarchical structure of the SWOT analysis that has been mapped. The highest level is the objective or focus of the problem being studied, and at the second level is reduced to the SWOT group. The third level outlines the factors associated with each SWOT group. The lowest level is the choice of strategies related to all SWOT factors. 


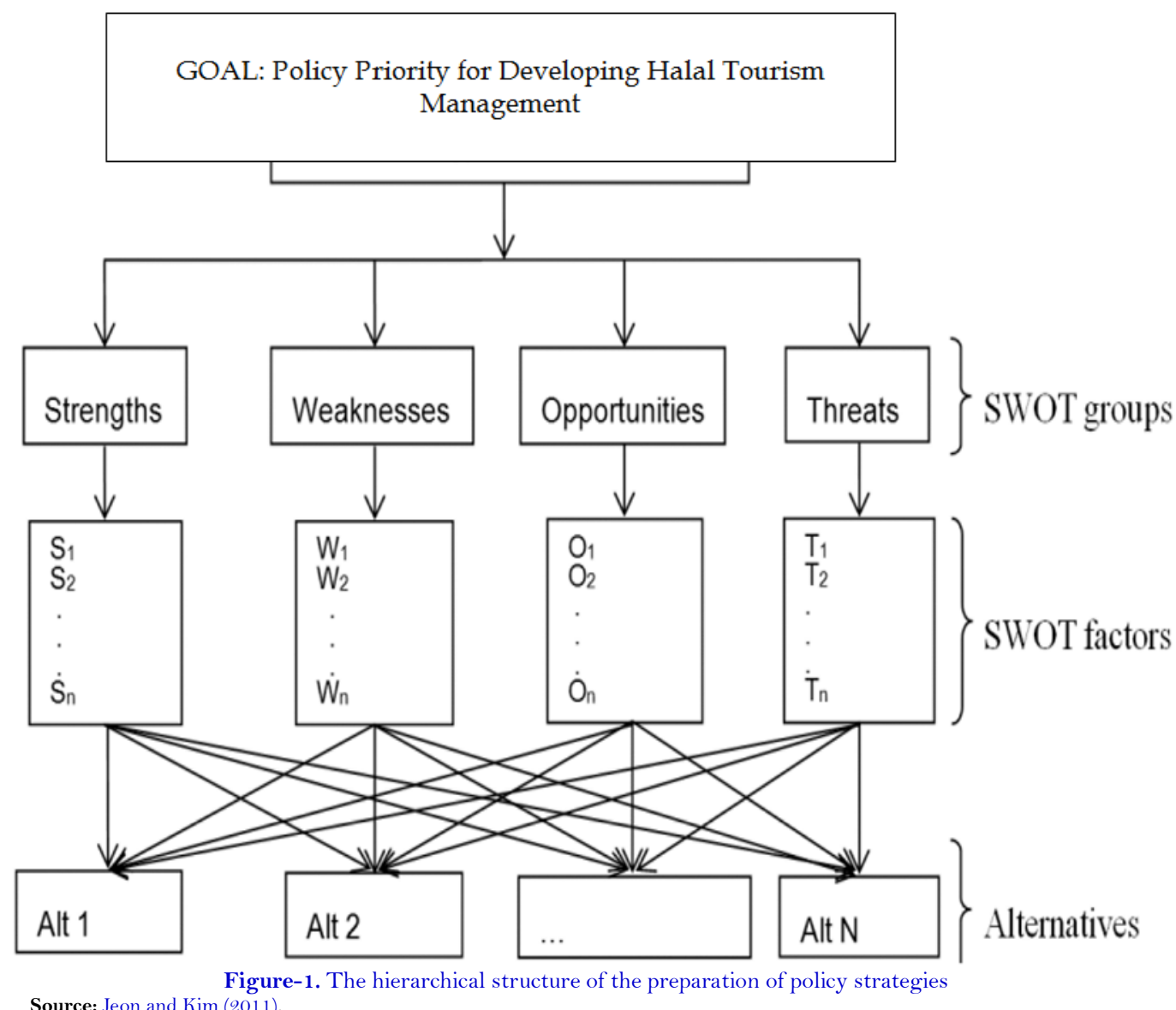

3. Build comparison matrices at each level of the hierarchy that is interrelated with the levels above it. This comparison matrix is built based on the perceptions or opinions of evaluators by comparing criteria or choices (SWOT group and SWOT factor). The value used to assess how important the two criteria are compared the reference scale consisting of values 1 to 9 reflects the expression of an expert's assessment of the importance of the two criteria Table 2 .

Table-2. Questionnaire rating scale.

\begin{tabular}{c|l}
\hline Score & Definition \\
\hline 1 & Both criteria are equally important \\
\hline 3 & Criteria one is slightly more important than the other \\
\hline 5 & Criteria one is very important compared to the other \\
\hline 7 & Criteria one is clearly more important than other \\
\hline 9 & Criteria one is absolutely more important than the other \\
\hline Source: Jeon and Kim (2011).
\end{tabular}

4. Determine the global priority of the SWOT factor with priority weights at the level above it (the SWOT group). Also, do the process for evaluating strategy choices by calculating global priority strategy choices using the value of the global priority weighting of the SWOT factor.

\section{RESULTS AND DISCUSSION}

\subsection{Halal Tourism Development Model}

The preparation of the halal tourism development model in Bukittinggi City is based on directions from the Ministry of Tourism listed in Tourism Ministerial Regulation (Permen) No. 14 of 2016 concerning Guidelines for Sustainable Tourist Destinations. The ministerial regulation encourages the formation of a cross-sectoral 
Sustainable Tourism Stakeholder Forum with stakeholder elements that are Penta Helix. The identification of stakeholders and the roles they play based on the Penta Helix model is as follows (Aribowo et al., 2018; Junaid, 2019; Yuniningsih et al., 2019):

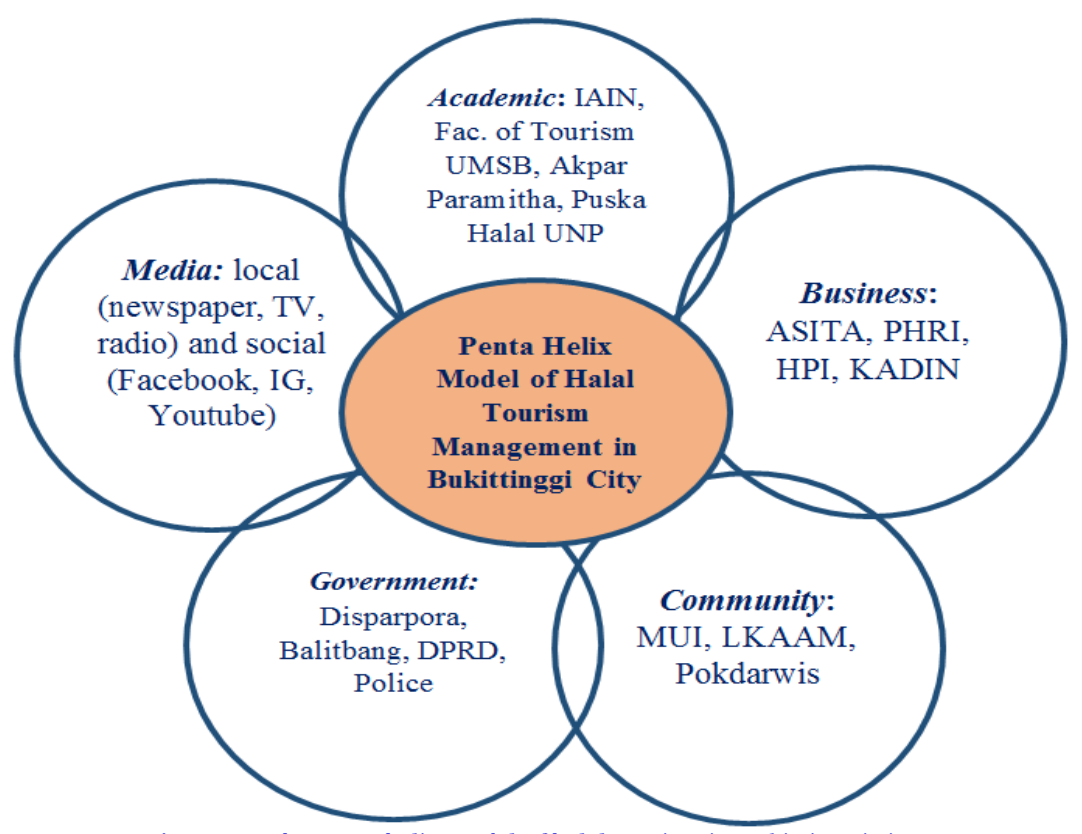

Figure-2. The penta helix model of halal tourism in Bukittinggi city.

The Penta Helix of halal tourism model in Figure 2 involving five parties who must support each other and work together (based on interviews with experts).

\subsection{Academic}

Several universities/college in Bukittinggi City that need to be involved include: 1) State Islamic Institute (IAIN) of Bukittinggi: a study of Islamic law perspective and support of Arabic language skills (promotion for Muslim countries and Middle Eastern tourist guides). Also, the opening of the Department of Islamic Tourism since 2017 will be able to prepare human resources in the field of Islamic tourism in the next 2 to 3 years; 2 ) The Faculty of Tourism of UMSB Bukittinggi and the Paramitha Tourism Academy: provide tourism industry human resources and producers of tourism concepts (research results), as well as certification of related tourism fields; 3) Padang State University, Center of Halal Study: provides socialization, education, and also facilitates halal product guarantee and halal MUI certification.

\subsection{Business}

Some of the organizations that facilitate tourism industry businesses in Bukittinggi City are as follows: Association of the Indonesian Tours \& Travel Agencies (ASITA), Indonesian Restaurant Hotel Association (PHRI), Indonesian Guides Association (HPI), and Chamber of Commerce and Industry (Kadin). Tourism businesses are at the forefront of implementing the concept of halal tourism. Therefore, they must be able to understand the concept of halal tourism and have the support and ease in implementing various ideas. For example, education and assistance in handling halal product certification are some of the essential things they need.

\subsection{Community}

Some communities that have a significant role in Bukittinggi City are as follows: 1) Indonesian Ulama Council (MUI): as an institution that provides advice and supervision in terms of the compatibility between tourism business practices with Islamic sharia provisions (as the Sharia Supervisory Board in Sharia Banking). MUI also 
acts as a conveyor of the Muslims' aspirations in maintaining Ummah to always be under Islamic teachings; 2) Lembaga Kerapatan Adat Alam Minangkabau (LKAAM): as an institution tasked to protect and preserve Minangkabau customs and culture. LKAAM plays a vital role in the daily life of the people of Bukittinggi City. The clash between Minangkabau customs-culture and tourism businesses (especially tourists from out of town) can be avoided if LKAAM can play an active role; 3) Tourism Awareness Group (Pokdarwis): a group of people who are directly involved in the tourism business in Bukittinggi City. Various existing tourism potency will not run if it does not include the community around the tourist destination.

\subsection{Government}

In practice, the active role of various Technical Implementation Units (UPT) in the Bukittinggi City Government to handling the tourism industry. For example, the Office of Public Works and Public Housing provides a variety of tourism infrastructure or the Department of Transportation that regulates the smooth flow of traffic and others. However, the main stakeholders of tourism policy in Bukittinggi City are as follows: 1) Bukittinggi City Tourism Agency: plays a role as the leading tourism sector in Bukittinggi City. This office has a task in formulating, implementing, and evaluating various technical policies in the field of tourism in Bukittinggi City (Disparpora, 2017) Bapelitbang of Bukittinggi City: tasked with conducting various research and policy development for the advancement of tourism in Bukittinggi City in the short and long term; 3) Local House of Representative (DPRD) of Bukittinggi city: although it does not play a role as a regulator, the DPRD is essential in producing regulations that support the development of halal tourism, as well as supervising the work of the city government; 4) Police: the effort to create an orderly and safe atmosphere for tourists is one of the main tasks of the police, as well as generating traffic arrangements, etc.

\subsection{Media}

Media plays a crucial role in preaching, promoting, and marketing tourist destinations and agendas in Bukittinggi. Along with the times, the part of mass media is not only imposed on the mainstream media such as TV, newspapers, and radio, but also social media, which increasingly plays a role in people's lives. Some press in Bukittinggi City are: 1) Newspaper: Singgalang, Padang Ekspres, Haluan; 2) Radio: RRI Bukittinggi, Izzis FM, Swara Kencana, Elsi FM, Jelita FM, Jam Gadang FM, Bimantara FM, dan Gipsi FM; 3) Television: TVRI Sumbar, BiTV, and Triarga TV; 4) Social Media: the admin of social media accounts that present the main content about Bukittinggi City on YouTube, Facebook, and Instagram. For example, 3 Instagram accounts are managed by the private with the name "Bukittinggi," which have very many followers, namely "Bukittinggiku" (152 thousand), "kaba.bukittinggi" (40.2 thousand), and "Bukittinggi24 hours" (39.7 thousand). While, the Instagram account managed by the Bukittinggi City Tourism Office "bukittinggitourism" was only followed by 1,689 followers (as of November 25, 2019). The same thing also happens on other social media platforms, such as Facebook and YouTube.

\subsection{Policy Priorities for Halal Tourism Management in Bukittinggi City}

The method used to set priorities for halal tourism management policies in Bukittinggi City is a combination of Analytical Hierarchy Process (AHP), and strengths, weaknesses, opportunities and threats analysis methods or commonly referred to as A 'WOT. As explained in the research methods section, the first stage of the A'WOT process is to analyze internal and external factors for the development of halal tourism (Fabac \& Zver, 2011).

The A'WOT method is used to obtain a halal tourism development strategy in Bukittinggi City. The determination of the criteria in the development strategy is based on the SWOT analysis by determining the factors that are considered to influence the development of halal tourism. The results of the AHP analysis are in the form of a policy priority sequence in determining the halal tourism development strategy. 
Researchers do the decomposition or also called the preparation of the hierarchy is the initial resistance in the AHP method. At this stage, complex or unstructured problems will be broken down into groups and then arranged in a hierarchical form. This study uses a type of hierarchy, interconnected between a level with a hierarchy at the level above it Jeon and Kim (2011); Kamal and Shabgoo (2017). The strategy for the development of halal tourism in Bukittinggi City consists of four SWOT groups as the result of Focus Group Discussion (FGD):

a. SWOT factor for Maximizing Strength $(S)$

The requirements for maximizing power are divided into four alternative policies:

1) The wealth of tourist destination $\left(S_{1}\right)$ : Bukittinggi City is famous for the diversity of attractions ranging from historical tourism, natural tourism, cultural tourism to shopping tourism.

2) Minang's philosophy of life $\left(\mathrm{S}_{2}\right)$ : In addition to being recognized for its wide selection of attractions, Bukittinggi City also upholds its customs. One of them is by preserving Minang's philosophy of life “Adat Basandi Syarak, Syarak Basandi Kitabullah.”

3) A large number of Muslims and places of worship $\left(S_{3}\right)$ : A large number of Muslims is one of the strengths of Bukittinggi City in developing halal tourism. With a large number of Muslims, certain places of worship are also easy to access.

4) Availability of adequate tourism infrastructure $\left(S_{4}\right)$ : Infrastructure is one of the considerations of tourists visiting a tourist attraction. Infrastructure will affect the safety and comfort of tourists when traveling.

\section{b. SWOT factor for Overcoming Weaknesses $(W)$}

1) Lack of tourism promotion $\left(\mathrm{W}_{1}\right)$ : Lack of promotion of tourism is a weakness that must be solved. With the significant publicity, tourism objects in Bukittinggi City will be easily recognized by outside parties, including foreign countries. With the recognition of attractions in Bukittinggi City, it will increase visits both from within the country and abroad.

2) Limited halal restaurants and Islamic hotels $\left(\mathrm{W}_{2}\right)$ : Halal restaurants and hotels have become a necessity for tourists, especially tourists who come from out of town. Tourists will consider attractions that are close to restaurants and inns so that they are easily accessible. But the existence of halal restaurants and sharia-certified hotels officially around the tourist attractions are still limited in number.

3) Understanding the concept of halal tourism is still lacking $\left(\mathrm{W}_{3}\right)$ : Not many people know the concept of halal tourism, especially the citizen. Understanding of halal tourism is essential to make people aware, so they can develop and support halal tourism in the City of Bukittinggi.

\section{c. SWOT factor for Utilizing Opportunities $(O)$}

1) Central and local government support $\left(\mathrm{O}_{1}\right)$ : Support from the central and regional governments for halal tourism is an opportunity to develop halal tourism in Bukittinggi City. The government should support and facilitate the process of developing halal tourism.

2) Foreign Muslim Tourist Interests $\left(\mathrm{O}_{2}\right)$ : Halal tourism is not only in demand by local and domestic tourists. Muslim tourists from the Middle East and other region are starting to be attracted by halal tourism in Bukittinggi City.

3) Awareness of the importance of halal products $\left(\mathrm{O}_{3}\right)$ : The majority of Bukittinggi people are Muslim, so they are aware of the importance of halal products, including in the tourism sector.

4) The collaboration of all halal tourism parties $\left(\mathrm{O}_{4}\right)$ : The development of halal tourism management needs cooperation between tourism institutions and stakeholders in Bukittinggi city. 


\section{d. SWOT factor for Minimizing Threats (T)}

1) Non-Muslim tourists are reluctant to travel $\left(T_{1}\right)$ : One of the threats that come when halal tourism starts to develop is that non-Muslim tourists are unwilling to go feeling minority.

2) The threat of shifting local culture $\left(T_{2}\right)$ : fears of changing local culture as a result of foreign cultural influences.

3) Competition with similar tourism objects $\left(\mathrm{T}_{3}\right)$ : Competition with similar tourist objects has an impact on the closed threat of attractions.

Based on the results of data processing from the AHP questionnaire to the expert respondents, the group priority values are obtained as listed in Table 3. The priority values of the SWOT groups are Opportunities (37.43\%), Weakness (25.53\%), Strengths (21.94) \%), and Treatments (15.10\%). Subsequent calculations produce priority of factor within group and then overall priority of factor that compare the fourteen factors in the whole group. The rightmost column of Table 4 shows the overall priority of factor values, as well as the order of priority factors from the largest (1) to the smallest (14).

Table-3. Matrix of SWOT factor evaluation.

\begin{tabular}{|c|c|c|c|c|}
\hline SWOT Groups & $\begin{array}{c}\text { Group } \\
\text { priority }\end{array}$ & $\begin{array}{l}\text { SWOT } \\
\text { Factors }\end{array}$ & $\begin{array}{l}\text { Priority of factor } \\
\text { within group }\end{array}$ & $\begin{array}{c}\text { Overall priority of } \\
\text { factor }\end{array}$ \\
\hline \multirow{4}{*}{ Strengths } & \multirow{4}{*}{$\begin{array}{c}0,2194 \\
(3)\end{array}$} & $\mathrm{S}_{1}$ & $0,2209 \quad(3)$ & $0,0485 \quad(11)$ \\
\hline & & $\mathrm{S} 2$ & $0,3621 \quad(1)$ & $0,0795 \quad(6)$ \\
\hline & & S3 & $0,1153 \quad(4)$ & $0,0253 \quad(13)$ \\
\hline & & $\mathrm{S} 4$ & $0,3016 \quad(2)$ & $0,0662 \quad(9)$ \\
\hline \multirow{3}{*}{ Weakness } & \multirow{3}{*}{$\begin{array}{c}0,2553 \\
(2)\end{array}$} & W1 & $0,4241 \quad(1)$ & 0,1083 \\
\hline & & $\mathrm{W} 2$ & $0,3180 \quad(2)$ & $0,0812 \quad(5)$ \\
\hline & & W3 & $0,2578 \quad(3)$ & $0,0658 \quad(10)$ \\
\hline \multirow{4}{*}{ Opportunities } & \multirow{4}{*}{$\begin{array}{c}0,3743 \\
(1)\end{array}$} & $\mathrm{O} 1$ & $0,1957 \quad(3)$ & $0,0732 \quad(7)$ \\
\hline & & $\mathrm{O} 2$ & $0,1835 \quad(4)$ & 0,0687 \\
\hline & & O3 & $0,2293 \quad(2)$ & 0,0858 \\
\hline & & $\mathrm{O} 4$ & $0,3913 \quad(1)$ & $0,1464 \quad(1)$ \\
\hline \multirow{3}{*}{ Threats } & \multirow{3}{*}{$\begin{array}{c}0,1510 \\
(4)\end{array}$} & $\mathrm{T} 1$ & $0,2974 \quad(2)$ & $0,0449 \quad(12)$ \\
\hline & & $\mathrm{T} 2$ & $0,5694 \quad(1)$ & $0,0859 \quad(3)$ \\
\hline & & T3 & $0,1330 \quad(3)$ & $0,0201 \quad(14)$ \\
\hline
\end{tabular}

Global priority values in Table 3 can be transformed in more detail in Figure 3. Based on Figure 3, it can be concluded that the SWOT group that becomes the priority of halal tourism development is taking advantage of opportunities. The support of the central and regional governments, the interest of foreign tourists, awareness of the importance of halal tourism, and collaboration between tourism people are opportunities for the development of halal tourism in Bukittinggi City.

The second priority of SWOT group is to overcome weaknesses, while the problems that arise in the development of tourism are the lack of tourism promotion outside the region, the limited halal restaurants and hotels, and the lack of public understanding of halal tourism. The third SWOT group that becomes a priority for the development of halal tourism is maximizing strength. Strengths in halal tourism in Bukittinggi City are a wealth of attractions, preservation of Minang philosophy of life, large numbers of Muslims and places of worship, and the availability of adequate infrastructure. The last SWOT group is to minimize threats. Threats experienced by halal tourism in Bukittinggi City are non-Muslim tourists who are reluctant to travel to halal tourism, the threat of shifting local culture, and competition of similar tourist objects.

From the results of the calculation of the final weights, we will know the priority order. Figure 3 shows the value weights for each SWOT factor and alternative. Alternatives are prepared based on SWOT factor that have been developed previously, where alternative policies aim to determine policy priorities in the context of the development of halal tourism. 


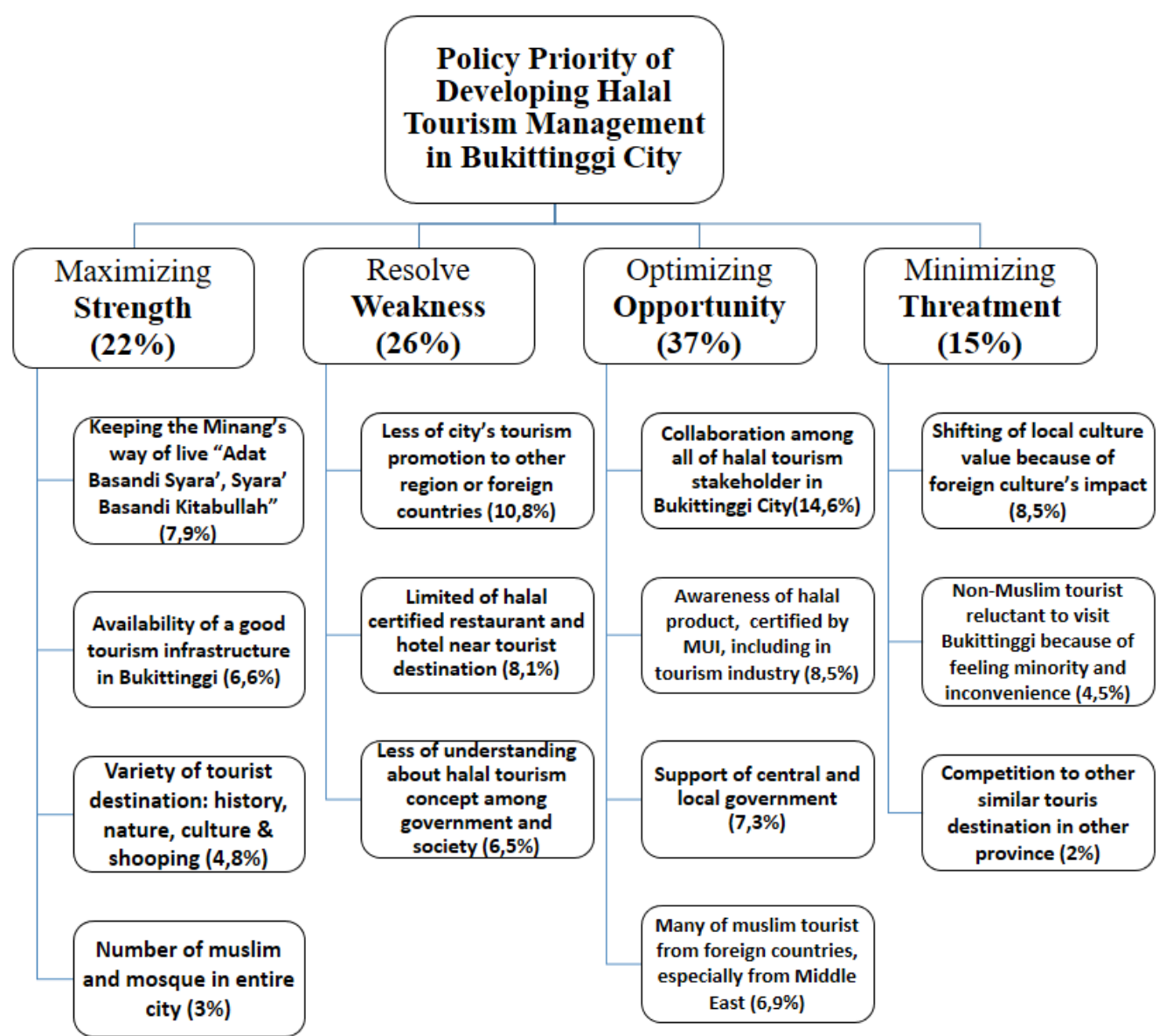

Figure-3. Results of priority selection policy for Halal tourism development in Bukittinggi City. Source: Data processing results.

Based on the results of calculations show that collaboration with tourism stakeholders in Bukittinggi City is a top priority in the development of halal tourism with a weight of $14.8 \%$. Bukittinggi City itself already has several tourism organizations or organizations that have contributed to the development of tourism such as PHRI, ASITA, HPI, and other association of tourism entrepreneurs. Equipped with all components in the Penta Helix Halal Tourism model Figure 1, it will produce constructive collaboration for the development of halal tourism in Bukittinggi City.

The second policy priority is to overcome the lack of tourism promotion to other regions and abroad. One of the policies of the city government in the tourism development strategy is tourism marketing through print and electronic media and websites. In addition to using print and electronic media, tourism marketing can also implement through tourism events at the local, national, and international scale. The Bukittinggi City Tourism Agency has carried out domestic and foreign tourism promotion 8 times domestically and 1 time abroad. Internal advertisements carried out/followed included in Bali, Batam, Yogyakarta, Jakarta (2 times), and Bukittinggi (2 times).

Meanwhile, overseas promotions were carried out in the form of ticket facilitation to Sanggar Gastarana to perform at cultural events in Bahrain (Disparpora, 2017). However, the promotional activities need to be evaluated for their effectiveness. Moreover, Bukittinggi City does not yet have an official branding event and city branding that results in a lack of focus and active promotion (Disparpora, 2017).

The third policy priority is to minimize the threat of shifting local culture to foreign culture. As research conducted in the city of Lombok, local governments need to socialize and translate the concept of halal tourism to the community. It is so that harmony between traditions, culture, and the environment of the city and the tourism industry takes place (Haris \& Nashirudin, 2019). 
The next policy priority is to take advantage of opportunities for public awareness of halal products. The Muslim community in Bukittinggi city surely supports the availability of various halal products. However, the complexity of the process and financing of halal certification is often a barrier. Therefore, the role of government is needed to solve this problem.

The fifth policy priority is to overcome the problem of limited Halal restaurants and certified Sharia hotels. Based on data on the 2016-2021 Bukittinggi City Disparpora Strategic Plan, the development of the tourism sector is supported by the contribution of tourism support sectors such as the trade, hotel and restaurant industry (20.71\%), the transportation and communication sector (23.08\%) and the service sector services (12.93\%). Overcoming the limitations of halal-certified hotels and restaurants is one of the efforts in the development of tourism in Bukittinggi City. There has been a guidance and development program for halal destinations in 2017 (IDR59 million) and 2018 (IDR65 million), but there are no more in the following years (Disparpora, 2017).

The program, according to the Head of Tourism and Creative Economy of Bukittinggi City, is realized in the form of facilitation of the management of MUI halal certification for several restaurants and restaurants in Bukittingi City. Implementation of Halal Product Guarantee Law number 33 of 2014 must involve various parties. Central and local governments need to simplify the process of halal product certification. Religious organizations such as Muhammadiyah and Nahdhatul Ulama must be involved in this program (Muslimin, 2019).

The next policy priority is to take advantage of opportunities for foreign Muslim tourists. International tourists have an interest in visiting natural attractions. The development of natural attractions is needed so that more and more foreign tourists visit. According to respondents, tourism in Bukittinggi City, in general, is following Islamic values (67\%). It is marked by the many worship facilities, religious customs \& culture, Islamic dress styles, and there are several sharia hotels. Therefore, Bukittinggi City has the vast potential to be developed as one of the main halal tourism destinations in Indonesia.

The strategies that need to be carried out by all tourism parties (Penta Helix model) in Bukittinggi City in the context of developing halal tourism can be described in the following SWOT matrix (Wickramasinghe \& Takano, 2010):

Table-4. SWOT-based policy strategy matrix for halal tourism in Bukittinggi city.

\begin{tabular}{|c|c|c|}
\hline & Strengths & Weaknesses \\
\hline $\begin{array}{l}\mathrm{O} \\
\mathrm{P} \\
\mathrm{P} \\
\mathrm{O} \\
\mathrm{R} \\
\mathrm{T} \\
\mathrm{U} \\
\mathrm{N}\end{array}$ & $\begin{array}{l}\text { S-O Strategies: Maxi-Maxi } \\
\text { (maximizing both strength and opportunities) } \\
\text { - Optimizing local government support to } \\
\text { provide tourism infrastructure and } \\
\text { preservation of Minangkabau philosophy } \\
\text { - Socialization of halal tourism through } \\
\text { printed and electronic media to provide } \\
\text { understanding to the public who are still } \\
\text { laymen because the majority of Bukittinggi } \\
\text { City residents are already Muslim, then this } \\
\text { socialization will be easily accepted }\end{array}$ & $\begin{array}{l}\text { W-O Strategies: Mini-Maxi } \\
\text { (minimizing weakness and maximizing opportunities) } \\
\text { - Increase promotion abroad, especially countries } \\
\text { in the Middle East, where many countries are } \\
\text { predominantly Muslim } \\
\text { - Develop cooperation with stakeholders, } \\
\text { especially to add halal restaurants and Islamic } \\
\text { hotels around the tourist attractions } \\
\text { - Ease of licensing by the government to provide } \\
\text { halal certificates to halal restaurants and sharia } \\
\text { hotels } \\
\text { Providing dissemination of the concept of halal } \\
\text { tourism to tourism operators and the public, } \\
\text { bearing in mind that many people have begun to } \\
\text { realize the importance of halal products }\end{array}$ \\
\hline
\end{tabular}




\begin{tabular}{|c|c|c|}
\hline $\begin{array}{l}\mathrm{T} \\
\mathrm{H} \\
\mathrm{R} \\
\mathrm{E} \\
\mathrm{A} \\
\mathrm{T} \\
\mathrm{S}\end{array}$ & $\begin{array}{l}\text { S-T Strategies: Maxi-Mini } \\
\text { (maximizing strength and minimizing threat) } \\
\text { - To protect the local culture from the } \\
\text { negative effect of foreign cultures, it is } \\
\text { necessary to have awareness and efforts to } \\
\text { preserve local culture and philosophy of } \\
\text { Minangkabau through tourism program } \\
\text { - One of the efforts so that tourism in the City } \\
\text { of Bukittinggi can compete with tourism } \\
\text { outside the region is to innovate and improve } \\
\text { infrastructure continuously }\end{array}$ & $\begin{array}{l}\text { W-T Strategies: Mini-Mini } \\
\text { (minimizing both weakness and threat) } \\
\text { - Reduce various obstacles in the halal } \\
\text { certification process, especially restaurants, } \\
\text { hotels, and various food products } \\
\text { - Promotion of tourism through electronic media } \\
\text { and websites to be able to reach market share } \\
\text { outside the City of Bukittinggi }\end{array}$ \\
\hline
\end{tabular}

The Bukittinggi city government can apply 4 general policy concepts based on the SWOT analysis: 1) maximizing the strength $(\mathrm{S})$ and opportunity $(\mathrm{O})$; 2) minimizing of weaknesses (W) and maximizing the opportunity $(\mathrm{O}) ; 3)$ maximizing the strength $(\mathrm{S})$ and reducing the threat $(\mathrm{T}) ; 4)$ minimizing of weaknesses $(\mathrm{W})$ and threats (T). The combination of AHP and SWOT (A'WOT) analysis methods results in a more structured policy priority order (Oreski, 2012). In this context, the policy priorities of halal tourism development in the City of Bukittinggi have been successfully formulated. The next stage is the implementation of the halal tourism development policy, which involves all parties in the Penta Helix model. The policy execution must include 5 related parties: Academic, Business, Community, Government, and Media (ABCGM).

\section{CONCLUSION}

Based on the results of the study, it can be concluded that Halal Tourism Management in Bukittinggi City, West Sumatra Province, with the Penta Helix model, must involve various parties, namely academics, practitioners/business, government, society, and the media. Collaboration among all components is needed. Policy priorities that must be selected and implemented by the Bukittinggi City government and all tourism personnel to develop halal tourism include 1) collaboration with all tourism people; 2) overcome the lack of promotion of outward tourism (regions/countries) involving various parties and media; 3) Minimizing the threat of shifting local culture due to foreign cultural influences; 4) Increase awareness of the importance of halal products, including in the field of tourism; and 5) Overcoming the limitations of halal restaurants and hotels certified by MUI. Future research needs to focus on developing the concept of halal tourism in areas that are predominantly non-Muslim to find solutions to the frequent conflicts between tourism managers and the surrounding population.

Funding: This study received no specific financial support.

Competing Interests: The authors declare that they have no competing interests.

Acknowledgement: Authors are grateful to the Research Centre of Sunan Kalijaga State

Islamic University for generously funding this research.

\section{REFERENCES}

Agus, B., Syahrizal, \& Meiyenti, S. (2006). A study of the application of the basic philosophy of Basandi Syarak-Syarak Basandi Kitabullah in West Sumatra. Padang: BPP Prov. West Sumatra.

Agustin, D. (2019). World Halal tourism award 2017, Malaysia and Turkey remain as heavy competitors for Indonesia. Retrieved from https://republika.co.id/berita/ekonomi/syariah-ekonomi/16/12/22/oik6ve374-world-halal-tourismaward-2017-malaysia-dan-Turkey-remains-a-heavy-competitor-Indonesia. [Accessed November 19, 2019].

Aribowo, H., Wirapraja, A., \& Putra, Y. D. (2018). Implementation of the pentahelix collaboration model in the framework of developing the potential of tourism in East Java and increasing the domestic economy. Journal of MEBIS: Management and Business, 3(1), 31-38.

Bhuiyan, M. A. H., Siwar, C., Ismail, S. M., \& Islam, R. (2011). Potentials of Islamic tourism: A case study of Malaysia on East Coast Economic Region. Australian Journal of Basic and Applied Sciences, 5(6), 1333-1340. 
Disparpora. (2017). Renstra of the City of Bukittinggi tourism, youth and sports office. Bukittinggi: Department of Tourism, Youth and Sports.

Elfisha, M. (2019). West sumatra targets completion of the regional regulation on halal tourism by 2020. Retrieved from https://sumbar.antaranews.com/berita/309624/sumbar-targetkan-perda-wisata-halal-selfinished-2020. [Accessed November 30, 2019].

Fabac, R., \& Zver, I. (2011). Applying the modified SWOT-AHP method to the tourism of Gornje Međimurje. Tourism and Hospitality Management, 17(2), 201-215.

Haris, H., \& Nashirudin, M. (2019). Lombok as an Indonesian halal travel destination. Shirkah: Journal of Economics and Business, $4(3), 482-492$.

Harnida, \& Tahir, M. (2012). The role of local government in the development of the rammang-rammang forest tourism object in Maros Regency. Authority: Journal of Governmental Science, 2(2), 125-136.

Hung, K. Y., Lin, M. H., \& Hsueh, S. L. (2018). A study on tourism development strategy of Kaohsiung City in Taiwan after urban style regeneration. KnE Social Sciences, 3(10), 1617-1629. Available at: https://doi.org/10.18502/kss.v3i10.3497.

Ismet, E., \& Abuhjeeleh, M. (2016). The analysis of tourism policies by different governments and their potential implementation in north cyprus economy. Journal of Political Sciences \& Public Affairs, 4(4), 2332-0761.1000221. Available at: https://doi.org/10.4172/2332-0761.1000221.

Jaelani, A. (2017). Halal tourism industry in Indonesia: Potential and prospects. International Review of Management and Marketing, 7(3), 25-34.

Jeon, Y. A., \& Kim, J. (2011). An application of SWOT-AHP to develop a strategic planning for a tourist destination. Paper presented at the 16th Graduate Students Research Conference, Houston, Texas.

Junaid, I. (2019). Synergy model of tourism pentahelix elements in the management of tourism destinations in the city of parepare and bone regency. Sociohumanities, 21(1), 22-33. Available at: https://doi.org/10.24198/sosiohumaniora.v2111.17016.

Kamal, Z. G. M., \& Shabgoo, M. S. M. (2017). Strategic planning for Halal tourism development in Gilan Province. Iranian Journal of Optimization, 9(1), 49-55.

Kangas, J., Pesonen, M., Kurttila, M., \& Kajanus, M. (2001). A'WOT: Integrating the AHP with SWOT analysis. Paper presented at the 6th ISAHP.

Kubickova, M. (2016). The role of government in tourism: linking competitiveness, freedom, and developing economies. Czech Journal of Tourism, 5(2), 73-92. Available at: https://doi.org/10.1515/cjot-2016-0005.

Mansouri, S. (2014). Role of Halal Tourism ideology in destination competitiveness: A study on selected hotels in Bangkok, Thailand. Paper presented at the International Conference on Law, Education and Humanities (ICLEH'14) Jan. 30-31, 2014 Pattaya (Thailand). Pattaya.

Masful, M. F. (2017). Halal tourism: A value of local wisdom and belief concept in rural area Pilubang Payakumbuh, West Sumatera. The Messenger, 9(1), 1-8.

Masyrifina, I. (2019). West Sumatra Halal tourism Perda completed this Year. Retrieved from https://www.republika.co.id/berita/ekonomi/syariah-ekonomi/19/03/25/poxcoz415-perda-wisata-halal-sumbarrampung-tahun-this. [Accessed November 19, 2019].

Muhyi, H. A., Chan, A., Sukoco, I., \& Herawaty, T. (2017). The Penta Helix collaboration model in developing centers of flagship industry in Bandung city. Review of Integrative Business and Economics Research, 6(1), 412-417.

Muslimin, J. (2019). Halal product guarantee in Indonesia regulation and social inclusion. Shirkah: Journal of Economics and Business, $4(1), 27-48$.

OKI-SESRIC. (2017). Strategic roadmap for development of islamic tourism in OIC member countries. Ankara, 3(2), 80.

Oreski, D. (2012). Strategy development by using SWOT-AHP. Tem Journal, 1(4), 283-291.

Ozdemir, Y., \& Demirel, T. (2018). Prioritization of tourism strategies in Turkey using a SWOT-AHP analysis. International Journal of Business and Industrial Marketing, 3(2), 34-45. 
Putiah, J. D. M. N. (2007). Mambangkik Batang Tarandam in an effort to leave and preserve Minangkabau adat in facing the modernization of national life. Bandung: Citra Umbara.

Ruano, M. (2018). Decision making within the tourism industry with AHP: Determining key influential factors affecting foreign visitors' decision to revisit Belize, Central America. Ph.D. Program in Management - College of Management Decision.

Simamora, R. K., \& Sinaga, R. S. (2016). The role of local government in the development of natural and cultural tourism in North Tapanuli Regency. Journal of Governmental and Socio-Political Sciences, 4(1), 79-96.

Suradin, M. (2018). Halal tourism promotion in Indonesia: An analysis on official destination websites. Journal of Indonesian Tourism and Development Studies, 6(3), 143-158. Available at: https://doi.org/10.21776/ub.jitode.2018.006.03.01.

Taherdoost, H. (2017). Decision making using the analytic hierarchy process (AHP); A step by step approach. International Journel of Economics and Management Systems, 2(1), 244-246.

Tarigan, Y. A., \& Alfindo, O. (2019). Bukittinggi City in numbers 2019. Bukittinggi, 25(1), 1-399.

Teguh, F. (2017). Tourism development strategy: Indonesia's synergy in managing tourism complexity (pp. 87). Jakarta: Kemenpar RI.

Vieira, I., Rodrigues, A., Fernandes, D., \& Pires, C. (2016). The role of local government management of tourism in fostering residents' support to sustainable tourism development: Evidence from a Portuguese historic town. International Journal of Tourism Policy, 6(2), 109-135.

Wickramasinghe, V., \& Takano, S. (2010). Application of combined SWOT and analytic hierarchy process (AHP) for tourism revival strategic marketing planning: A case of Sri Lanka tourism. Journal of the Eastern Asia Society for Transportation Studies, 8(3), 954-969.

Wulandari, S. H., Chotijah, S., \& Suadnya, I. W. (2019). The Mandalika special economic zone (KEK) marketing communication strategy as a priority tourism destination post the 2018 Lombok earthquake. Journal of Media and Communication Science, 2(3), 158-167.

Yan, L. S., Zahari, N. A., Ismail, A. S., \& Zain, N. M. (2017). Halal tourism: A new world for tourism industry. International Journal of Asian Social Science, 7(8), 643-657. Available at: https://doi.org/10.18488/journal.1.2017.78.643.657.

Yunas, N. S. (2019). Implementation of the Penta Helix concept in developing village potentials through the village economic granary model in East Java Province. Renewal Matrix, 3(1), 37-46. Available at: https://doi.org/10.21787/mp.3.1.2019.37-46.

Yuniningsih, T., Darmi, T., \& Sulandari, S. (2019). Pentahelic model in tourism development in Semarang City. Journal of Public Sector Innovation, 3(2), 84-93.

Zuhriyah, D. A. (2019). Halal tourism development: Kemenparekraf targets 4 Million muslim tourists next Year. Retrieved from https://ekonomi.bisnis.com/read/20191025/12/1163265/pengembangan-wisata-halal-kemenparekraf-targetkan-4juta-wisman-muslim-tahun-depan. [Accessed November 19, 2019].

Views and opinions expressed in this article are the views and opinions of the author(s), International Journal of Publication and Social Studies shall not be responsible or answerable for any loss, damage or liability etc. caused in relation to/arising out of the use of the content. 